Neuroepidemiology 2011;36:77-78

DOI: $10.1159 / 000323572$

\section{Essential Tremor: One of the Most Common Neurodegenerative Diseases?}

Julián Benito-León ${ }^{\mathrm{a}, \mathrm{b}}$

a Department of Neurology, University Hospital '12 de Octubre', and ${ }^{b}$ Centro de Investigación Biomédica en Red sobre

Enfermedades Neurodegenerativas (CIBERNED), Madrid, Spain

Louis et al. [1] estimated the prevalence of essential tremor (ET) in a population-based study in Araihazar, Bangladesh, a developing country. As part of an in-person evaluation in a health outcomes study, each study participant produced 2 handwriting samples, from which ET diagnoses were assigned by 2 independent movement disorder neurologists. The crude prevalence of ET (age $\geq 18$ years) was 19/1,229 [1.5\%, 95\% confidence interval $(\mathrm{CI})=1.0-2.4]$, and was similar in men and women. The crude prevalence was $2.5 \%$ in participants aged $\geq 40$ years and one half that $(1.3 \%)$ among younger participants ( $<40$ years).

The results of this study are of special interest. Aside from the fact that no other prevalence studies of ET have been conducted in Bangladesh, the investigators did not rely on indirect assessment tools (screening questionnaires). Instead, they collected handwriting (direct) data of all study participants.

The study had several strengths, including the large sample size, the population-based design and the well-thought-out approach to the statistical analyses. However, the study was not without limitations. As noted by the authors, participants with Parkinson's disease (PD) were excluded based on history rather than neurological examination, raising the possibility that a small number of PD cases were undiagnosed. It is possible that some of the putative ET cases had action tremor due to PD rather than ET. Given the reliance on handwriting samples for establishing ET diagnoses, misclassification is certainly possible. The authors were aware of the limitations and, to their credit, provided a thoughtful discussion of these issues and why they thought these issues were of minor concern in this study.

Leaving aside issues of strengths and limitations, the study again demonstrates that ET is among the most common neurological diseases. How does the prevalence of ET, in general, compare with other neurological disorders of later life [2]? In a population-based study in central Spain (NEDICES), the prevalence of ET [4.8\% (95\% CI $=4.2-5.4)]$ [3] was higher than the prevalence of all types of parkinsonism [2.2\% $(95 \% \mathrm{CI}=1.8-2.6)]$ [4] and similar to that of cerebrovascular disease, including stroke and transient ischemic attack $[4.9 \%(95 \% \mathrm{CI}=4.3-5.5)]$ [5]. How- ever, it was slightly less than that of dementia $[5.8 \%(95 \% \mathrm{CI}=$ 5.2-6.5)] [6].

ET was for many years viewed merely as a benign symptomatic condition, yet over the past 10 years, a growing body of evidence indicates that this is a progressive condition that is not monosymptomatic but is clinically heterogeneous [7-9]. The weight of emerging evidence is indicating that, aside from motor manifestations, ET is also associated with a number of non-motor manifestations, including cognitive deficits [10-12], dementia [13, 14], personality changes [15], depressive symptoms [16], possible mild olfactory dysfunction [17], and hearing impairment [18]. Furthermore, emerging pathological studies are providing evidence that ET is likely to be a neurodegenerative disease that is pathologically heterogeneous [19]. Given its high prevalence, this would make ET the most common neurodegenerative disease aside from Alzheimer's disease.

\section{Acknowledgement}

Dr. Benito-León is supported by NIH R01 NS039422 from the National Institutes of Health, Bethesda, Md., USA.

\section{References}

1 Louis ED, Hafeman D, Parvez F, Alcalay RN, Islam T, Siddique AB, Patwary TI, Melkonian S, Argos M, Levy D, Ahsan H: Prevalence of essential tremor in Araihazar, Bangladesh: a population-based study. Neuroepidemiology 2011;36:71-76.

2 Benito-León J: How common is essential tremor? Neuroepidemiology 2009;32:215-216.

-3 Benito-León J, Bermejo-Pareja F, Morales JM, Vega S, Molina JA: Prevalence of essential tremor in three elderly populations of central Spain. Mov Disord 2003;18:389-394.

4 Benito-León J, Bermejo-Pareja F, Rodríguez J, Molina JA, Gabriel R, Morales JM, Neurological Disorders in Central Spain (NEDICES) Study Group: Prevalence of PD and other types of parkinsonism in three elderly populations of central Spain. Mov Disord 2003;18:267274.

5 Díaz-Guzmán J, Bermejo-Pareja F, Benito-León J, Vega S, Gabriel R, Medrano MJ, Neurological Disorders in Central Spain (NEDICES) Study Group: Prevalence of stroke and transient ischemic attack in three elderly populations of central Spain. Neuroepidemiology 2008; 30:247-253.

-6 Bermejo-Pareja F, Benito-León J, Vega S, Olazarán J, de Toledo M, Díaz-Guzmán J, Sánchez-Sánchez F, Morales-González JM, Trincado R, Portera-Sánchez A, Román GC: Consistency of clinical diagnosis of dementia in NEDICES: a population-based longitudinal study in Spain. J Geriatr Psychiatry Neurol 2009;22:246-255.

7 Benito-León J, Louis ED: Essential tremor: emerging views of a common disorder. Nat Clin Pract Neurol 2006;2:666-678.

8 Benito-León J, Louis ED: Clinical update: diagnosis and treatment of essential tremor. Lancet 2007;369:1152-1154.

-9 Benito-León J: Essential tremor: from a monosymptomatic disorder to a more complex entity. Neuroepidemiology 2008;31:191-192.

\section{KARGER}

(C) 2011 S. Karger AG, Basel

Fax +41613061234 E-Mail karger@karger.ch www.karger.com 
-10 Benito-León J, Louis ED, Bermejo-Pareja F, Neurological Disorders in Central Spain (NEDICES) Study Group: Population-based case-control study of cognitive function in essential tremor. Neurology 2006;66: 69-74.

11 Louis ED, Benito-León J, Vega-Quiroga S, Bermejo-Pareja F, Neurological Disorders in Central Spain (NEDICES) Study Group: Cognitive and motor functional activity in non-demented community-dwelling essential tremor cases. J Neurol Neurosurg Psychiatry 2010;81:9971001.

- 12 Louis ED, Benito-León J, Vega-Quiroga S, Bermejo-Pareja F, Neurological Disorders in Central Spain (NEDICES) Study Group: Faster rate of cognitive decline in essential tremor cases than controls: a prospec tive study. Eur J Neurol 2010;17:1291-1297.

-13 Benito-León J, Louis ED, Bermejo-Pareja F, Neurological Disorders in Central Spain Study Group: Elderly-onset essential tremor is associated with dementia. Neurology 2006;66:1500-1505.

-14 Bermejo-Pareja F, Louis ED, Benito-León J, Neurological Disorders in Central Spain (NEDICES) Study Group: Risk of incident dementia in essential tremor: a population-based study. Mov Disord 2007;22:15731580.

-15 Chatterjee A, Jurewicz EC, Applegate LM, Louis ED: Personality in essential tremor: further evidence of non-motor manifestations of the disease. J Neurol Neurosurg Psychiatry 2004;75:958-961.
16 Louis ED, Benito-León J, Bermejo-Pareja F, Neurological Disorders in Central Spain (NEDICES) Study Group: Self-reported depression and anti-depressant medication use in essential tremor: cross-sectional and prospective analyses in a population-based study. Eur J Neurol 2007;14: 1138-1146.

17 Louis ED, Jurewicz EC: Olfaction in essential tremor patients with and without isolated rest tremor. Mov Disord 2003;18:1387-1389.

18 Benito-León J, Louis ED, Bermejo-Pareja F, Neurological Disorders in Central Spain (NEDICES) Study Group: Reported hearing impairment in essential tremor: a population-based case-control study. Neuroepidemiology 2007;29:213-217.

19 Louis ED: Essential tremor: evolving clinicopathological concepts in an era of intensive post-mortem enquiry. Lancet Neurol 2010;9:613622.

Dr. Julián Benito-León

Department of Neurology, University Hospital '12 de Octubre'

Av. de Córdoba, s/n

ES-28041 Madrid (Spain)

Tel./Fax +34913908600, E-Mail jbenitol@meditex.es 